\title{
Effectiveness of resistance programs in wheelchair users shoulder function: A
} systematic review

\section{Eficácia dos programas de exercício resistido na função do ombro de usuários de cadeira de rodas: Uma revisão sistemática}

\author{
DOI: $10.46814 / 1 a j d v 4 n 1-007$
}

Recebimento dos originais: 01/12/2021

Aceitação para publicação: 24/01/2022

\section{María Campayo Piernas (Campayo-Piernas, M.)}

Higher academic background: $\mathrm{PhD}$

Independent autor

C/ Los Lucios 32, 2B, 30006, Murcia, Spain

E-mail: maria.campayo@goumh.es

\section{José Luis Hernández Davó, (Hernández-Davó, J.L.) \\ Higher academic background: $\mathrm{PhD}$ \\ Faculty of Health Sciences, Universidad Isabel I \\ 09003, Burgos, Spain \\ E-mail: jlhdez43@gmail.com}

\section{João Bruno Granada Maia (Granada-Maia, J.B.)}

Higher academic background: BD

Faculty of Health Sciences, Universidad Isabel I

09003, Burgos, Spain

E-mail: brunoextremadura@gmail.com

\section{Renata Matheus Willig (Willig, R.M.)}

Higher academic background: $\mathrm{PhD}$

Current Institution: KinesioLab - Unidade de Investigação em Análise do Movimento, Instituto

Piaget de Almada, Almada, Portugal (Filiation 1)

Center of Studies in Physical Activity and Sports for People with Disabilities -

NEAFEP/UNIFESP (Filiation 2)

Avenida Jorge Peixinho, n³0, Quinta da Arreinela, 2805-059, Almada, Portugal.

E-mail: rewillig@gmail.com

\begin{abstract}
Literature presents promising results regarding exercise programs to reduce shoulder pain in manual wheelchair users. However, there is a lack of systematization and specific usefulness of resistance training programs. Thus, the study objective was to analyze the effectiveness of resistance training programs in reducing shoulder pain, and to increase shoulder strength and function in manual wheelchair users (MWUs). A Boolean search strategy adapted for Pubmed, Ebsco, Scopus, Web of Science and Scielo Science databases was undertaken (up to February 2021) to identify all studies measuring changes in shoulder strength, pain, and/or function after implementing a resistance training program in MWUs. Two independent reviewers selected articles based on following criteria: MWUs, participants' age, study design and intervention types. Also, reviewers performed the study quality
\end{abstract}


assessment, risk-of-bias analysis and data extraction. Of the 124 obtained publications, a total of 9 studies met the inclusion criteria, being evaluated through PEDro Scale (mean quality score in four or below) and uncertain risk of bias according to Cochrane Scale assessment. The studies shows that: onerepetition maximum (12-60\%), isometric peak force (25-36\%) and isokinetic muscle strength (10-30\%) increased following resistance training interventions. Significant reductions (22-85\%) in shoulder pain (WUSPI score) were found after resistance training interventions. In addition, shoulder function (evaluated by DASH questionnaire) improved (12-60\%) following resistance training. The present review highlights the usefulness of resistance training programs to improve muscular strength and shoulder function and to reduce shoulder pain in MWUs. These results have significant practical applications to improve the quality of life of MWUs.

Keywords: manual wheelchair user, resistance training and shoulder pain.

\section{RESUMO}

A literatura apresenta resultados promissores acerca de programas de exercício físico para reduzir a dor no ombro de usuários de cadeira de rodas manual. No entanto, existe uma carência da sistematização e da utilidade específica dos programas de treinamento resistido. Assim, o objetivo deste estudo foi analisar a eficácia dos programas de treinamento de resistência na redução da dor no ombro, aumento da força e função do ombro em usuários de cadeira de rodas manual (UCRM). Uma estratégia de busca booleana adaptada foi utilizada nos bancos de dados Pubmed, Ebsco, Scopus, Web of Science e Scielo Science (até fevereiro de 2021) para identificar todos os estudos que mediam mudanças na força, dor e/ou função do ombro após a implementação de um programa de treinamento resistido em UCRM. Dois revisores independentes selecionaram os artigos com base nos seguintes critérios: UCRM, idade dos participantes, desenho do estudo e tipos de intervenção. Além disso, os revisores realizaram a avaliação da qualidade do estudo, análise de risco de viés e extração dos dados. Das 124 publicações obtidas, um total de 9 estudos atenderam aos critérios de inclusão, sendo avaliados por meio da Escala PEDro (escore de qualidade médio de quatro ou menos) e risco de viés incerto, de acordo com a avaliação da Escala Cochrane. Os estudos mostram que: uma repetição máxima (12$60 \%)$, pico de força isométrica (25-36\%) e força muscular isocinética (10-30\%) aumentaram após intervenções de treinamento resistido. Reduções significativas (22-85\%) na dor no ombro (pontuação do WUSPI) foram encontradas após as intervenções de treino resistido. Além disso, a função do ombro (avaliada pelo questionário DASH) melhorou (12-60\%) após o treinamento resistido. A presente revisão destaca a utilidade de programas de treinamento resistido para melhorar a força muscular e função do ombro, e reduzir a dor no ombro em UCRM. Esses resultados têm aplicações práticas significativas para melhorar a qualidade de vida dos UCRM.

Palavras-chaves: usuário de cadeira de rodas manual, treinamento resistido e dor no ombro.

\section{INTRODUCTION}

The wheelchair is one of the most used mobility devices by people with disabilities for their mobility. ${ }^{54}$ The manual wheelchair users (MWUs) constantly depend on the upper limbs to provide independent mobility. ${ }^{41}$ Daily life activities, weight relief, transfers, and the repetitive load induced by the propulsion of the manual wheelchair cause considerable stress on the upper limbs, especially on the shoulders. ${ }^{29,50,54}$ Consequently, shoulder pain is prevalent among MWUs. ${ }^{29}$ 
In this context, the pathologies associated with upper limbs in the MWUs may result in a loss of autonomy, a sedentary lifestyle and excluding social situations. ${ }^{5,16}$ Adapted physical activity is a route to social inclusion, with shoulder injuries complicating participation in this type of program, and consequently, affecting psychological well-being, leading to low self-esteem and sedentary lifestyles. ${ }^{13}$ Facing this problem, the inclusion of physical activities has been associated with greater independence, increased physical well-being and positive impact on rehabilitation. ${ }^{14}$ Previous research has shown that shoulder pain is significantly reduced after exercise-based interventions. ${ }^{9,29}$ Increasing the knowledge about the risk factors and mechanisms leading to shoulder pain in MWUs will help in the appropriate selection of exercise program contents.

It is widely accepted that the cause of shoulder pain in this population is multifactorial. ${ }^{15,19}$ Among these factors, presenting lower strength values in shoulder external rotator muscles is linked to an increased risk to suffer from shoulder pain. ${ }^{33,48,50}$ Consequently, some authors have suggested strength training as a viable strategy to decrease the risk of suffering shoulder pain. ${ }^{19}$ Specifically, the strengthening of shoulder adductors and shoulder internal rotators have been proposed as a key component of exercise programs aiming to reduce shoulder pain. ${ }^{7,11}$

Despite the promising results of exercise-based intervention in reducing shoulder pain in MWUs, to date, there is not a compendium of research assessing the specific usefulness of resistance training programs for this purpose. Thus, the aims of this review were (1) to examine the literature about effectiveness of resistance training programs in reducing shoulder pain in MWUs, (2) to assess the influence of resistance training programs on strength gains and shoulder function in MWUs.

\section{METHODS}

This systematic review was conducted according to the Preferred Reporting Items for Systematic Reviews and Meta-Analyses (PRISMA) recommendation. ${ }^{31}$

The following inclusion criteria were adopted to study selection: (a) studies involved MWUs adults (> 18 years old); (b) studies that included a resistance training program; (c) randomized controlled trials, uncontrolled clinical trials and quasi-experimental studies that reported shoulder pain measures with data at baseline and post resistance training intervention. Also, exclusion criteria were: (a) studies that sample includes power wheelchair users, children or adolescents; (b) observational, cross-sectional, case and case-control studies; (c) intervention program that did not included resistance exercise, as well as did not report duration, frequency and intensity of the exercise program; d) studies that do not report measures by shoulder pain. 
The Pubmed, Ebsco, Scopus, Web of Science and Scielo Science databases were searched only for full journal peer-reviewed articles published in English, Portuguese, and Spanish language until February 2021. The search was performed between the $1^{\text {st }}$ and $10^{\text {th }}$ of February 2021. The search strategy included a standard protocol using three keywords groups (manual wheelchair user, resistance training and shoulder pain, last two based in Mesh term for MEDLINE) and their respective synonymous: "manual wheelchair user*" OR "wheelchair user*" OR "wheelchair" AND "resist* exercise*” OR "resist* training" OR "resist*program*” OR "strength* exercise*” OR "strength* training*" OR "strength* program*” OR "weight* exercise*” OR "weight* training*" OR "weight* program*” AND shoulder OR "shoulder pain*”.

Data were screened and extracted independently by reviewers (J.H and J.G) using standardized forms. Reviewers screened the titles and duplicates were eliminated. After each author screened titles and abstracts and the conflicts were automatically added to the full-text review. The full-text review and reasons for exclusion were also independently assessed. Conflicts were decided with the other reviewers (M.C. and R.W). Additionally, other systematic reviews and references of the included studies were manually consulted to ensure no other relevant studies had been missed in the search strategy. If necessary, the corresponding author was contacted to clarify the included articles data.

Sample characteristics (size, age and disability), intervention (type, duration, frequency and intensity), outcomes and shoulder pain data were extracted independently by J.H. The second reviewer (J.G.) checked the extracted outcomes. The disagreements were resolved with a debate among all reviewers.

The quality of studies was assessed by PEDro Scale. ${ }^{32}$ This scale evaluates the following 11 items: (1) participants' eligibility; (2) random distribution; (3) concealed distribution; (4) comparison of groups at baseline; (5) blinding of participants; (6) blinding of therapist; (7) blinding of evaluators; (8) measurement of at least one key outcome in $85 \%$ of subjects allocated; (9) intention to treat; (10) comparison between groups; (11) measures of accuracy and variability. A study received 1 point if it met the requirement for the item and 0 points if it did not. The final score is the sum of 10 items (2-11 items), where the higher scores indicate better methodological quality. ${ }^{32}$

Cochrane Scale assessed the risk of bias through a scale that contains 7 items: (1) randomization; (2) allocation concealment; (3) blinding of participants; (4) blinding of evaluators; (5) incomplete outcome data; (6) selective reporting; (7) other sources of bias. Each item was evaluated as low, high, or uncertain. The risk of bias was classified as: low risk - all items received a low-risk assessment; high risk - if any item received high-risk classification; uncertain risk - if at least one item received the uncertain classification. ${ }^{20}$ 


\section{RESULTS}

Figure 1 shows the flow diagram for the extracted studies for this systematic review. The literature search provided a total of 124 records and three studies were identified in a manual search. A total of 127 were identified. Subsequently, 54 duplicate studies were eliminated. After excluding duplicates, 73 papers remained, from which 46 were excluded after reading the titles (18 papers) and abstracts (28 papers) since they did not meet the inclusion criteria. Moreover, 27 full-text studies assessed eligibility and a total of 18 papers were removed after failing to meet the eligibility criteria, 9 by type of study ( 7 type of study design and two were only the clinical trials registered), 2 by sample characteristics, 3 by intervention characteristics and 4 by reported outcomes. Therefore, 9 studies ${ }^{12,22,25,28,34-36,42,49}$ met the selection criteria and were included in this review. Moreover, Table 1 shows the selected study characteristics.

Table 2 presents the methodological quality of the Study. Through PEDro Scale analysis, on a range scale 1 to 10 , only one study ${ }^{34}$ presented score nine. While the other studies had a score $4,25,35,36$ $3^{22,49}$ and $2 .^{12,28,42}$ Furthermore, Table 3 shows the risk of bias analysis. All studies ${ }^{12,22,25,28,35,36,42,49}$ had an uncertain risk of bias, except one ${ }^{34}$ that presented high risk.

FIGURE 1. PRISMA flow diagram.

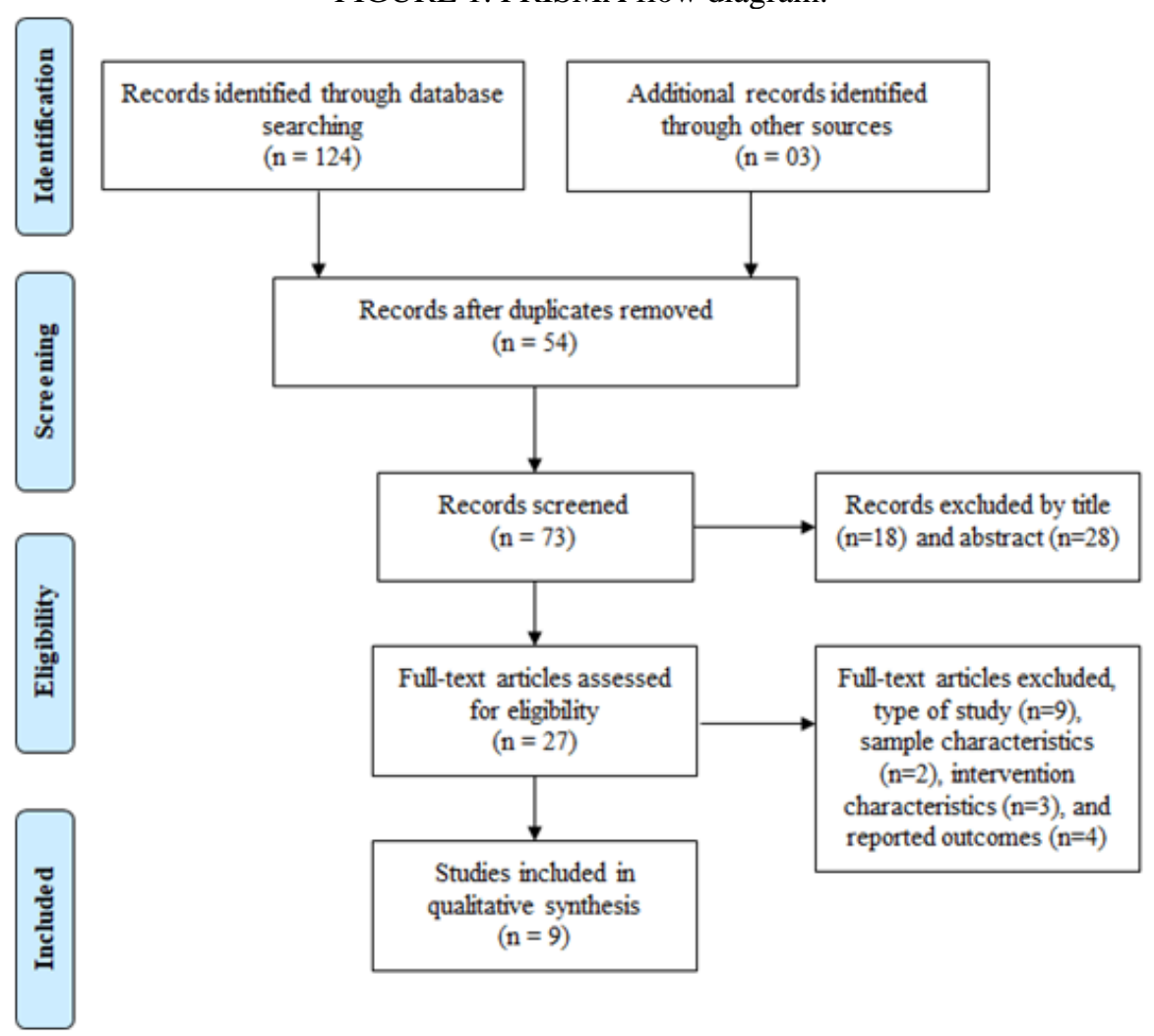




\subsection{STRENGTH}

Seven of the nine articles included in the review performed pre-to-post strength evaluations. Specifically, three studies ${ }^{12,22,35}$ included a 1-RM test, showing all of them significant improvements in 1-RM, with increases ranging from 11.9 to $59.7 \%$. Isokinetic muscle strength tests were used in three articles, ${ }^{22,34,42}$ and significant improvements (10-30\%) were found in all articles. Isometric peak force was evaluated in two articles ${ }^{25,28}$, with both articles showing significant increases in isometric peak force (25-36\%), although Lins et al. ${ }^{28}$ showed non-significant increases in isometric shoulder internal rotation force. Finally, one $\operatorname{study}^{12}$ used a strength-endurance test, showing significant increases in the number of repetitions performed in $30 \mathrm{~s}(10-61 \%)$. 
LATIN AMERRICAN

TABLE 1. Characteristics of the studies included.

\begin{tabular}{|c|c|c|c|c|}
\hline Article & Sample & Training intervention & Outcomes & Results \\
\hline $\begin{array}{l}\text { Durán et } \\
\text { al. }^{12}\end{array}$ & $\begin{array}{c}13 \text { subjects }(12 \mathrm{M}, 1 \mathrm{~F}) \\
26.3 \pm 8.3 \text { years } \\
\text { Thoracic spinal cord injury } \\
\text { (T6 and higher } n=4 \text {; below } \\
\text { T6 } n=9)\end{array}$ & $\begin{array}{c}16 \text { weeks } \\
3 \text { sessions of } 120 \mathrm{~min} / \text { week } \\
\text { Combined aerobic, mobility, coordination, and } \\
\text { strength } \\
7 \text { exercises (BP, MP, BUP, DB, DT, SA, CBN) } \\
\text { No information about number of sets, repetitions, } \\
\text { intensity, or movement velocity }\end{array}$ & $\begin{array}{c}\text { 1-RM in BP, MP, BUP } \\
\text { Repetitions in } 30 \text { seconds in DB, DT, } \\
\text { SA and CBN } \\
\text { Functional Independence Measure } \\
\text { (FIM) }\end{array}$ & $\begin{array}{l}\text { 1-RM increased } 14-46 \% \\
\text { Repetitions in } 30 \text { seconds } \\
\text { increased } 10-61 \% \\
\text { FIM improved } 5.3-7.6 \text { points }\end{array}$ \\
\hline $\begin{array}{l}\text { Jacobs et } \\
\text { al. }^{22}\end{array}$ & $\begin{array}{l}10 \text { male subjects } \\
39.4 \pm 6 \text { years } \\
\text { Paraplegia }\end{array}$ & $\begin{array}{c}12 \text { weeks } \\
3 \text { sessions of } 45 \text { min/week } \\
\text { Circuit resistance training } \\
6 \text { exercises (MP, HOR, PD, PUD, CB, SD) } \\
3 \text { sets x } 10 \text { repetitions with 50-60\% 1-RM using } \\
\text { a } 3 \text { s tempo }\end{array}$ & $\begin{array}{l}\text { Concentric and eccentric isokinetic } \\
\text { strength: elbow flexion and extension, } \\
\text { shoulder external and internal } \\
\text { rotation, shoulder flexion and } \\
\text { extension, shoulder abduction and } \\
\text { adduction } \\
\text { Isoinertial strength: 1-RM for the } \\
\text { exercises included in the training } \\
\text { program }\end{array}$ & $\begin{array}{l}\text { Concentric isokinetic strength } \\
\text { improved in } 6 \text { exercises } \\
\text { Eccentric isokinetic strength } \\
\text { improved in } 3 \text { exercises } \\
\text { 1-RM increased } 11.9-30.2 \%\end{array}$ \\
\hline $\begin{array}{l}\text { Kim et } \\
\mathrm{al}^{25}\end{array}$ & $\begin{array}{c}11 \text { subjects } \\
36.8 \pm 6.9 \text { years } \\
\text { Spinal cord injury }(\mathrm{C} 4-\mathrm{L} 1)\end{array}$ & $\begin{array}{c}6 \text { weeks } \\
3 \text { sessions of } 60 \mathrm{~min} / \text { week } \\
\text { Combined aerobic and resistance training } \\
9 \text { muscle groups (exercises based on the level of } \\
\text { injury) } \\
1-3 \text { sets x } 10-20 \text { repetitions with a RPE intensity } \\
\text { increasing over the weeks (from } 4 \text { to } 8 \text { ) }\end{array}$ & $\begin{array}{c}\text { Isometric peak force: Elbow flexion } \\
\text { and extension, shoulder abduction and } \\
\text { adduction, shoulder flexion and } \\
\text { extension }\end{array}$ & $\begin{array}{l}\text { Isometric peak force increased in } \\
\text { all the exercises }(32-36 \%)\end{array}$ \\
\hline $\begin{array}{c}\text { Lins et } \\
\text { al. }^{28}\end{array}$ & $\begin{array}{l}17 \text { subjects } \\
40.0 \pm 10.0 \text { years } \\
\text { Spinal cord injury } \\
\text { (tetraplegia } C 4-C 7 \text { ) }\end{array}$ & $\begin{array}{c}12 \text { weeks } \\
4 \text { sessions/week } \\
5 \text { exercises with elastic band (shoulder external } \\
\text { rotation x2, low-row, push-ups and horizontal } \\
\text { abductions) } \\
3 \text { sets of } 15 \text { repetitions } \\
\text { Medium-resistance band (weeks 1-6) and heavy- } \\
\text { resistance band (weeks 7-12) }\end{array}$ & $\begin{array}{l}\text { Isometric peak force: Internal and } \\
\text { external rotation } \\
\text { Upper-limb functionality (DASH } \\
\text { score) }\end{array}$ & $\begin{array}{l}\text { Isometric peak external rotation } \\
\text { force increased significantly (25- } \\
\qquad 30 \% \text { ) } \\
\text { Isometric peak internal rotation } \\
\text { did not significantly change } \\
\text { Clinically relevant decreases in } \\
\text { DASH score }\end{array}$ \\
\hline $\begin{array}{l}\text { Mulroy } \\
\text { et al. }{ }^{34}\end{array}$ & $\begin{array}{c}40 \text { subjects }(31 \mathrm{M}, 9 \mathrm{~F}) \\
47 \pm 9 \text { years }\end{array}$ & $\begin{array}{c}12 \text { weeks } \\
3 \text { sessions/week }\end{array}$ & $\begin{array}{l}\text { Isokinetic peak force: Shoulder } \\
\text { adduction, elevation, internal and }\end{array}$ & $\begin{array}{l}\text { Isokinetic peak force increased in } \\
\text { all the exercises } 18-30 \%\end{array}$ \\
\hline
\end{tabular}




\begin{tabular}{|c|c|c|c|c|}
\hline & $\begin{array}{l}\text { Spinal cord injury (T2-T7 } n \\
=27 ; \mathrm{T} 8 \text { and below } n=13)\end{array}$ & $\begin{array}{c}\text { Combined stretching and resistance training } \\
4 \text { exercises (HOR, LR, SA, SER) } \\
3 \text { sets x } 8 \text { RM (SA, SER) and } 3 \text { sets x } 15 \text { RM } \\
\text { (HOR, LR) }\end{array}$ & $\begin{array}{c}\text { external rotation } \\
\text { Shoulder pain (WUSPI) } \\
\text { Wheelchair propulsion speed } \\
\text { Subjective quality of life scale }\end{array}$ & $\begin{array}{l}\text { WUSPI scores decreased } 71 \% \\
\text { No changes in wheelchair } \\
\text { propulsion speed } \\
\text { Subjective quality of life increased } \\
10 \%\end{array}$ \\
\hline $\begin{array}{l}\text { Nash et } \\
\text { al. }^{35}\end{array}$ & $\begin{array}{l}7 \text { male subjects } \\
\text { 39-58 years } \\
\text { Spinal cord injury } \\
\text { (paraplegia; T5-T12) }\end{array}$ & $\begin{array}{c}16 \text { weeks } \\
3 \text { sessions of } 45 \text { min/week } \\
\text { Circuit resistance training } \\
6 \text { exercises (MP, BP, HR, CB, PUD, SD) } \\
3 \text { sets x } 10 \text { repetitions with } 50-60 \% \text { 1-RM using } \\
\text { a } 3 \text { s tempo }\end{array}$ & $\begin{array}{l}\text { 1-RM strength } \\
\text { Shoulder pain (WUSPI) }\end{array}$ & $\begin{array}{l}\text { 1-RM strength increased 38.6- } \\
\quad 59.7 \% \\
\text { WUSPI scores decreased } 85 \%\end{array}$ \\
\hline $\begin{array}{l}\text { Nawocze } \\
\text { nski et } \\
\text { al. }^{36}\end{array}$ & $\begin{array}{c}21 \text { subjects }(15 \mathrm{M}, 6 \mathrm{~F}) \\
47.1 \pm 11.7 \text { years } \\
\text { Spinal cord injury: } \\
\text { Paraplegia or incomplete } \\
\text { tetraplegia (Cervical } n=3 ; \\
\text { T2-T7 } n=7 ; \text { T8-T12 } n=7 ; \\
\text { lumbar } n=4)\end{array}$ & $\begin{array}{c}8 \text { weeks } \\
3-4 \text { sessions/week } \\
\text { Stretching and resistance training with elastic } \\
\text { bands } \\
4 \text { exercises (trapezius x2, serratus anterior and } \\
\text { SER) }\end{array}$ & $\begin{array}{l}\text { Shoulder pain (WUSPI) } \\
\text { Shoulder function: Shoulder Rating } \\
\text { Questionnaire (SRQ) }\end{array}$ & $\begin{array}{l}\text { Significant reduction in WUSPI } \\
\text { scores }(50 \%) \\
\text { Significant improvements in SRQ } \\
(24 \%)\end{array}$ \\
\hline $\begin{array}{l}\text { Serra- } \\
\text { Añó et } \\
\text { al. }^{42}\end{array}$ & $\begin{array}{c}15 \text { male subjects } \\
40.3 \pm 11.1 \text { years } \\
\text { Spinal cord injury (T4-T12) }\end{array}$ & $\begin{array}{c}8 \text { weeks } \\
3 \text { sessions/week } \\
8 \text { exercises (LR, PUD, HOR, CB, SIR, SER) } \\
3 \text { sets x 8-12 repetitions with an RPE intensity of } \\
7-8\end{array}$ & $\begin{array}{l}\text { Isokinetic strength: shoulder external } \\
\text { and internal rotation, shoulder flexion } \\
\text { and extension, shoulder abduction and } \\
\text { adduction } \\
\text { Shoulder pain (WUSPI) } \\
\text { Upper-limb functionality (DASH) }\end{array}$ & $\begin{array}{l}\text { Isokinetic strength increased 10- } \\
17 \% \\
\text { Significant reductions in WUSPI } \\
\text { scores (55\%) } \\
\text { Significant decreases in DASH } \\
\text { scores }(12 \%)\end{array}$ \\
\hline $\begin{array}{l}\text { Van } \\
\text { Straaten } \\
\text { et al. }^{49}\end{array}$ & $\begin{array}{c}16 \text { subjects }(13 \mathrm{M}, 3 \mathrm{~F}) \\
41 \text { years (range } 25-64) \\
\text { Spinal cord injury } \\
(\mathrm{C} 6-7 n=1 ; \mathrm{T} 2-\mathrm{T} 7 n=5 ; \\
\text { T8 and below } n=9) \text { Polio } n \\
=1\end{array}$ & $\begin{array}{c}12 \text { weeks } \\
\geq 3 \text { sessions/week } \\
3 \text { exercises (LWR, SER, SP) } \\
3 \text { sets x } 30 \text { repetitions }\end{array}$ & $\begin{array}{c}\text { Isometric peak force: shoulder } \\
\text { external and internal rotators, scapular } \\
\text { abductors and retractors, lower } \\
\text { trapezius } \\
\text { Shoulder pain (WUSPI) } \\
\text { Upper-limb functionality (DASH) } \\
\text { Shoulder function: Shoulder Rating } \\
\text { Questionnaire (SRQ) }\end{array}$ & $\begin{array}{l}\text { Significant reduction in WUSPI } \\
\text { scores }(45 \%) \\
\text { Significant decreases in DASH } \\
\text { scores }(60 \%) \\
\text { Significant improvements in SQR } \\
(9 \%)\end{array}$ \\
\hline
\end{tabular}

$\mathrm{BP}=$ Bench press; $\mathrm{BUP}=$ Butterfly press; $\mathrm{CB}=$ curl biceps; $\mathrm{CBN}=$ Curl back neck; $\mathrm{DB}=$ Dumbbell biceps; $\mathrm{DT}=$ Dumbbell triceps; $\mathrm{F}=$ Females; HOR = Horizontal row; $\mathrm{HRR}=$ Heart rate recovery $\mathrm{LR}=$ lateral rises LWR = low row; $\mathrm{M}=$ males; $\mathrm{MP}=$ Military press $; \mathrm{PD}=\mathrm{Pec}$ deck; $\mathrm{PESS}=$ Physical examination of the shoulder scale; $\mathrm{PNRS}=$ Pain numerical rating scale; $\mathrm{PUD}=$ Pull-down; RM= repetition maximum; $\mathrm{SA}=$ shoulder abduction; $\mathrm{SD}=$ seated dips; $\mathrm{SER}=$ shoulder external rotation; SIR = shoulder internal rotation; SP = shoulder punch; USPR S = Ultrasound shoulder pathology rating scale; WUSPI = Wheelchair user's shoulder pain index. 
LATIN AMERICAN

TABLE 2. PEDro Scale analysis.

\begin{tabular}{lcccccccccccc} 
& \multicolumn{10}{c}{ ' } \\
\hline Study & $\mathbf{1}$ & $\mathbf{2}$ & $\mathbf{3}$ & $\mathbf{4}$ & $\mathbf{5}$ & $\mathbf{6}$ & $\mathbf{7}$ & $\mathbf{8}$ & $\mathbf{9}$ & $\mathbf{1 0}$ & $\mathbf{1 1}$ & Score \\
\hline Durán et al. $^{12}$ & 1 & 0 & 0 & 0 & 0 & 0 & 0 & 0 & 0 & 1 & 1 & $2 / 10$ \\
Jacobs et al. $^{22}$ & 0 & 0 & 0 & 0 & 0 & 0 & 0 & 1 & 1 & 0 & 1 & $3 / 10$ \\
Kim et al. $^{25}$ & 1 & 0 & 0 & 0 & 0 & 0 & 0 & 1 & 1 & 1 & 1 & $4 / 10$ \\
Lins et al. $^{28}$ & 1 & 0 & 0 & 0 & 0 & 0 & 0 & 1 & 0 & 0 & 1 & $2 / 10$ \\
Mulroy et al. $^{34}$ & 1 & 1 & 1 & 1 & 1 & 1 & 1 & 0 & 1 & 1 & 1 & $9 / 10$ \\
Nash et al. $^{35}$ & 1 & 0 & 0 & 0 & 0 & 0 & 0 & 1 & 1 & 1 & 1 & $4 / 10$ \\
Nawoczenski et al. $^{36}$ & 1 & 0 & 0 & 0 & 0 & 0 & 0 & 1 & 1 & 1 & 1 & $4 / 10$ \\
Serra-Añó et al. $^{42}$ & 1 & 0 & 0 & 0 & 0 & 0 & 0 & 0 & 0 & 1 & 1 & $2 / 10$ \\
Van Straaten et al. $^{49}$ & 1 & 0 & 0 & 0 & 0 & 0 & 0 & 0 & 1 & 1 & 1 & $3 / 10$ \\
\hline
\end{tabular}

TABLE 3. Risk of bias of analyzed studies.

\begin{tabular}{|c|c|c|c|c|c|c|c|c|}
\hline Study & 1 & 2 & 3 & 4 & 5 & 6 & 7 & Risk \\
\hline Durán et al. $^{12}$ & Uncertain & Uncertain & Uncertain & Uncertain & Uncertain & Low & Uncertain & Uncertain \\
\hline Jacobs et al. ${ }^{22}$ & Uncertain & Uncertain & Uncertain & Uncertain & Uncertain & Low & Uncertain & Uncertain \\
\hline Kim et al. ${ }^{25}$ & Uncertain & Uncertain & Uncertain & Uncertain & Uncertain & Low & Uncertain & Uncertain \\
\hline Lins et al. ${ }^{28}$ & Uncertain & Uncertain & Uncertain & Uncertain & Uncertain & Low & Uncertain & Uncertain \\
\hline Mulroy et al. ${ }^{34}$ & Low & Low & High & High & High & Low & Low & High \\
\hline Nash et al. ${ }^{35}$ & High & Uncertain & Uncertain & Uncertain & Low & Low & Uncertain & Uncertain \\
\hline Nawoczenski et al. ${ }^{36}$ & Uncertain & High & High & Uncertain & High & Low & Uncertain & Uncertain \\
\hline Serra-Añó et al. ${ }^{42}$ & Uncertain & High & High & Low & Low & High & Low & Uncertain \\
\hline Van Straaten et al. ${ }^{49}$ & Uncertain & High & High & High & High & Low & Uncertain & Uncertain \\
\hline
\end{tabular}




\subsection{SHOULDER PAIN}

A total of five studies ${ }^{34-36,42,49}$ included shoulder pain assessment. All of them used the WUSPI, showing significant reductions ranging from 22 to $85 \%$.

\subsection{SHOULDER FUNCTION}

The DASH index was used as a measure of shoulder function in three studies, ${ }^{28,42,49}$ reporting all of them significant decreases in DASH score ranging from 12 to $60 \%$. It should be noted that a decrease in DASH score means an improved shoulder function. Two studies ${ }^{36,49}$ used the SQR to assess shoulder functionality, showing both of them significant increases (9-24\%).

\subsection{OTHERS}

Durán et al. ${ }^{12}$ reported significant increases in functional independence measure, while Mulroy et al. ${ }^{34}$ showed a $10 \%$ increase in subjective quality of life. Finally, Mulroy et al. ${ }^{34}$ reported nonsignificant changes in wheelchair propulsion speed.

\section{DISCUSSION}

The aims of the present review were to assess the usefulness of resistance training interventions in eliciting strength gains, shoulder pain reductions and improvements in shoulder function in manual wheelchair users. The main findings of this study were that upper-body strength and shoulder function increased after resistance training interventions, together with significant reductions in shoulder pain. However, due to the disparity in training interventions and testing procedures, further research is needed to elucidate the optimal resistance training regime for MWUs.

Resistance training has been suggested as a key factor to reduce both acute and overuse injury incidence, ${ }^{3,27}$ likely due to the established relationship between muscular weakness and a higher injury risk. ${ }^{37,39,44}$ The results of the present review highlight the great effectiveness of resistance training in improving shoulder strength. This has been proved in studies assessing either isometric, ${ }^{25,28}$ isokinetic $^{22,34,42}$ or isotonic ${ }^{12,22,35}$ shoulder strength values, which is in line with previous studies showing increases in shoulder strength after resistance training interventions in overhead athletes, ${ }^{38,45}$ and in subjects suffering from shoulder injuries. ${ }^{8}$ Although not measured in the articles included in the present review, improvements in strength as a result of resistance training are underpinned by multiple neural and morphological changes, such as increased rate and magnitude of motor unit activation, ${ }^{10,47}$ altered muscle architecture, ${ }^{1,6}$ and increased tendon stiffness. ${ }^{21,52}$ Previous research have revealed lower values of shoulder rotation strength as a predictive variable for upper-body injuries, ${ }^{2,4,18,23}$ suggesting that strength training interventions may play a key role in reducing shoulder injuries. The 
wide variety of resistance training interventions, including different equipment (e.g., elastic bands vs free weight) and specially, different programming variables (e.g., volume, intensity, density) and the small number of articles meeting inclusion criteria, makes impossible to propose any specific resistance training methodology as the most appropriate to increase muscular strength in MWUs. It should be highlighted that some of the research does not provide a proper description of key programming variables as training intensity, movement velocity and load progression. As adaptations following resistance training appears to be dependent on the optimal choice of resistance training programming variables, including the load mobilized and the movement velocity, ${ }^{26}$ there is a clear need for future high-quality studies assessing the effectiveness of well-described different resistance training programs in improving shoulder strength in MWUs.

The high muscular demands on the upper extremities in MWUs frequently result in shoulder pain and injury. ${ }^{51}$ Although the specific factors causing shoulder pain are not fully established, previous research has shown decreased muscle strength as a predictor of shoulder pain. ${ }^{34,48,50}$ Consequently, there is a rationale for implementing resistance training in MWUs training programs. Two previous reviews have shown that multicomponent exercise-based interventions are an effective strategy to reduce shoulder pain in MWUs. ${ }^{9,29}$ The present review demonstrates that exercise interventions based on resistance training are a powerful tool to reduce shoulder pain in MWUs. Although the sample used in the studies may have differed between them, shoulder pain assessed by the WUSPI showed significant reductions ranging from 22 to $85 \%$ (5 to 36 points). It should be noted that Cratsenberg et al. ${ }^{9}$ suggested a minimal detectable change in shoulder pain of 5.1 points when using the WUSPI score to assess the usefulness of an exercise-based intervention, which highlights the great effect of resistance training on shoulder pain reductions in MWUs. The high peak forces affecting shoulder joint together with the large number of movement repetition (i.e., wheelchair propulsion) have been linked to shoulder pain and injury in MWUs, ${ }^{30}$ which is usually manifested by decreases in strength and range of motion. ${ }^{53}$ Shoulder external rotator strength, scapular kinematics and shoulder external range of motion are the variables most likely affected in subjects suffering from shoulder pain. ${ }^{30,53}$ Therefore, resistance training interventions focused on shoulder external rotator muscles and scapular muscles (e.g., serratus, rhomboid, trapezius, supraspinatus) are highly recommended in MWUs with shoulder pain.

A concomitant effect of shoulder pain is a decrease in shoulder function, which affects MWUs quality of life. ${ }^{17,46}$ Exercise-based interventions have previously shown to enhance quality of life through improvements in shoulder function. ${ }^{9,24,43}$ The current review specifically presents resistance training as an optimal exercise strategy to improve shoulder function. This is supported by 5 out of 5 
articles showing significant improvements ranging from 9 to $60 \%$ in shoulder function following a resistance training intervention. Due to the highly negative influence of increased shoulder pain and reduced shoulder function in daily-living activities, including work outside the home and housework, ${ }^{40}$ there is a need to seek exercise-based strategies to increase shoulder function and consequently, the quality of life of MWUs. Based on the results found in the present review, resistance training is highly recommended when aiming to improve shoulder function in MWUs. Further, Durán et al. ${ }^{12}$ reported significant increases in functional independence, and Mulroy et al. ${ }^{34}$ reported a $10 \%$ increase in subjects' quality of life, which highlight the wide variety of benefits provided by strength training interventions.

The main limitations of the present study rely on the relatively small number of articles that meet inclusion criteria, and the discrepancies in methodologies used, which makes unable to suggest a superior effect of any resistance training program against others. The wide variety of intervention lengths (6-16 weeks), number of exercises used (from 3 to 9), type of muscular action assessed (e.g., isometric, isokinetic, isotonic), and the discrepancies in training intensity used and managed (i.e., RPE, elastic band resistance, [x] RM load) do not allow to provide recommendations for the most appropriate design of resistance training programs for MWUs. A training frequency of at least 3 sessions per week was used in all studies, which suggest this frequency as appropriate for strength training programs for MWUs, although future research should assess if lower training frequencies (e.g., 2 sessions per week) could result in similar functional improvements. Despite it was not a requisite in our search, all subjects have spinal cord injury in the make-up of the final sample, which do not allow extrapolation of the results to other populations. Furthermore, it was not achieved to make a comparison among injury types.

\section{CONCLUSION}

In conclusion, the present review highlights the usefulness of resistance training programs to improve muscular strength in MWUs. In addition, resistance training has been shown to significantly reduce shoulder pain and to improve shoulder function. These results have significant practical applications not only for rehabilitation processes, but also to improve the quality of life of MWUs. Despite the limitations found in the literature, resistance training appears as a highly recommended exercise-based strategy to reduce shoulder pain, and to increase muscular strength and shoulder function in MWUs. 


\section{REFERENCES}

1. Aagaard, P., Simonsen, E. B., Andersen, J. L., Magnusson, P., \& Dyhre-Poulsen, P. (2002). Increased rate of force development and neural drive of human skeletal muscle following resistance training. J Appl Physiol (1985), 93(4), 1318-1326. doi:10.1152/japplphysiol.00283.2002

2. Achenbach, L., Laver, L., Walter, S. S., Zeman, F., Kuhr, M., \& Krutsch, W. (2020). Decreased external rotation strength is a risk factor for overuse shoulder injury in youth elite handball athletes. Knee Surg Sports Traumatol Arthrosc, 28(4), 1202-1211. doi:10.1007/s00167-019-05493-4

3. Alentorn-Geli, E., Myer, G. D., Silvers, H. J., Samitier, G., Romero, D., Lázaro-Haro, C., \& Cugat, R. (2009). Prevention of non-contact anterior cruciate ligament injuries in soccer players. Part 2: a review of prevention programs aimed to modify risk factors and to reduce injury rates. Knee Surg Sports Traumatol Arthrosc, 17(8), 859-879. doi:10.1007/s00167-009-0823-z

4. Asker, M., Waldén, M., Källberg, H., Holm, L. W., \& Skillgate, E. (2020). Preseason clinical shoulder test results and shoulder injury rate in adolescent elite handball players: a prospective study. J Orthop Sports Phys Ther, 50(2), 67-74. doi:10.2519/jospt.2020.9044

5. Ballinger, D. A., Rintala, D. H., \& Hart, K. A. (2000). The relation of shoulder pain and rangeof-motion problems to functional limitations, disability, and perceived health of men with spinal cord injury: a multifaceted longitudinal study. Arch Phys Med Rehabil, 81(12), 1575-1581. doi:10.1053/apmr.2000.18216

6. Blazevich, A. J., Gill, N. D., \& Zhou, S. (2006). Intra- and intermuscular variation in human quadriceps femoris architecture assessed in vivo. J Anat, 209(3), 289-310. doi:10.1111/j.14697580.2006.00619.x

7. Burnham, R. S., May, L., Nelson, E., Steadward, R., \& Reid, D. C. (1993). Shoulder pain in wheelchair athletes. The role of muscle imbalance. Am J Sports Med, 21(2), 238-242. doi:10.1177/036354659302100213

8. Camargo, P. R., Avila, M. A., Alburquerque-Sendín, F., Asso, N. A., Hashimoto, L. H., \& Salvini, T. F. (2012). Eccentric training for shoulder abductors improves pain, function and isokinetic performance in subjects with shoulder impingement syndrome: a case series. Rev Bras Fisioter, 16(1), 74-83. doi:10.1590/s1413-35552012000100013

9. Cratsenberg, K. A., Deitrick, C. E., Harrington, T. K., Kopecky, N. R., Matthews, B. D., Ott, L. M., \& Coeytaux, R. R. (2015). Effectiveness of exercise programs for management of shoulder pain in manual wheelchair users with spinal cord injury. J Neurol Phys Ther, 39(4), 197-203. doi:10.1097/npt.0000000000000103

10. Del Vecchio, A., Casolo, A., Negro, F., Scorcelletti, M., Bazzucchi, I., Enoka, R., ... Farina, D. (2019). The increase in muscle force after 4 weeks of strength training is mediated by adaptations in motor unit recruitment and rate coding. J Physiol, 597(7), 1873-1887. doi:10.1113/jp277250

11. Diaz, R., Stoll, A. H., Rho, M. E., \& Blauwet, C. A. (2018). Preserving the shoulder function of an elite paratriathlete. Am J Phys Med Rehabil, 97(8), e69-e72. doi: $10.1097 / \mathrm{phm} .0000000000000870$

12. Durán, F. S., Lugo, L., Ramírez, L., \& Eusse, E. (2001). Effects of an exercise program on the rehabilitation of patients with spinal cord injury. Arch Phys Med Rehabil, 82(10), 1349-1354. doi:10.1053/apmr.2001.26066 
13. Ellapen, T. J., Hammill, H. V., Swanepoel, M., \& Strydom, G. L. (2017). The health benefits and constraints of exercise therapy for wheelchair users: A clinical commentary. Afr J Disabil, 6, 337. doi:10.4102/ajod.v6i0.337

14. Fasczewski, K. S., Gill, D. L., \& Rothberger, S. M. (2018). Physical activity motivation and benefits in people with multiple sclerosis. Disabil Rehabil, 40(13), 1517-1523. doi:10.1080/09638288.2017.1300946

15. Finley, M. A., \& Ebaugh, D. (2017). Association of pectoralis minor muscle extensibility, shoulder mobility, and duration of manual wheelchair use. Arch Phys Med Rehabil, 98(10), 2028-2033. doi:10.1016/j.apmr.2017.03.029

16. Finley, M. A., \& Euiler, E. (2020). Association of musculoskeletal pain, fear-avoidance factors, and quality of life in active manual wheelchair users with SCI: A pilot study. The Journal of Spinal Cord Medicine, 43(4), 497-504. doi:10.1080/10790268.2019.1565717

17. Gutierrez, D. D., Thompson, L., Kemp, B., \& Mulroy, S. J. (2007). The relationship of shoulder pain intensity to quality of life, physical activity, and community participation in persons with paraplegia. J Spinal Cord Med, 30(3), 251-255. doi:10.1080/10790268.2007.11753933

18. Hams, A. H., Evans, K., Adams, R., Waddington, G., \& Witchalls, J. (2019). Shoulder internal and external rotation strength and prediction of subsequent injury in water-polo players. Scandinavian Journal of Medicine \& Science in Sports, 29(9), 1414-1420. doi:https://doi.org/10.1111/sms.13459

19. Heyward, O. W., Vegter, R. J. K., de Groot, S., \& van der Woude, L. H. V. (2017). Shoulder complaints in wheelchair athletes: A systematic review. PLOS ONE, 12(11), e0188410. doi:10.1371/journal.pone.0188410

20. Higgins, J. P., Altman, D. G., Gøtzsche, P. C., Jüni, P., Moher, D., Oxman, A. D., . . Sterne, J. A. (2011). The Cochrane Collaboration's tool for assessing risk of bias in randomised trials. Bmj, 343, d5928. doi:10.1136/bmj.d5928

21. Hirayama, K., Iwanuma, S., Ikeda, N., Yoshikawa, A., Ema, R., \& Kawakami, Y. (2017). Plyometric training favors optimizing muscle-tendon behavior during depth jumping. Front Physiol, 8, 16. doi:10.3389/fphys.2017.00016

22. Jacobs, P. L., Nash, M. S., \& Rusinowski, J. W. (2001). Circuit training provides cardiorespiratory and strength benefits in persons with paraplegia. Med Sci Sports Exerc, 33(5), 711717. doi:10.1097/00005768-200105000-00005

23. Kekelekis, A., Nikolaidis, P. T., Moore, I. S., Rosemann, T., \& Knechtle, B. (2020). Risk factors for upper limb injury in tennis players: a systematic review. International journal of environmental research and public health, 17(8), 2744. doi:10.3390/ijerph17082744

24. Kemp, B. J., Bateham, A. L., Mulroy, S. J., Thompson, L., Adkins, R. H., \& Kahan, J. S. (2011). Effects of reduction in shoulder pain on quality of life and community activities among people living long-term with SCI paraplegia: a randomized control trial. J Spinal Cord Med, 34(3), 278-284. doi: $10.1179 / 107902611 \times 12972448729486$

25. Kim, D. I., Taylor, J. A., Tan, C. O., Park, H., Kim, J. Y., Park, S. Y., . . Jeon, J. Y. (2019). A pilot randomized controlled trial of 6-week combined exercise program on fasting insulin and fitness levels in individuals with spinal cord injury. Eur Spine J, 28(5), 1082-1091. doi:10.1007/s00586-01905885-7 
26. Kraemer, W. J., \& Ratamess, N. A. (2004). Fundamentals of resistance training: progression and exercise prescription. Med Sci Sports Exerc, 36(4), 674-688. doi:10.1249/01.mss.0000121945.36635.61

27. Lauersen, J. B., Andersen, T. E., \& Andersen, L. B. (2018). Strength training as superior, dosedependent and safe prevention of acute and overuse sports injuries: a systematic review, qualitative analysis and meta-analysis. British Journal of Sports Medicine, 52(24), 1557-1563. doi:10.1136/bjsports-2018-099078

28. Lins, C., Castro, A., Medina, G. I. S., Azevedo, E., Donato, B. S., Chagas, M. S. S., ... Cliquet, A., Jr. (2019). Alternative scapular stabilization exercises to target strength, endurance and function of shoulders in tetraplegia: A prospective non-controlled intervention study. J Spinal Cord Med, 42(1), 65-76. doi:10.1080/10790268.2017.1398943

29. Mason, B., Warner, M., Briley, S., Goosey-Tolfrey, V., \& Vegter, R. (2020). Managing shoulder pain in manual wheelchair users: a scoping review of conservative treatment interventions. Clinical Rehabilitation, 34(6), 741-753. doi:10.1177/0269215520917437

30. Mercer, J. L., Boninger, M., Koontz, A., Ren, D., Dyson-Hudson, T., \& Cooper, R. (2006). Shoulder joint kinetics and pathology in manual wheelchair users. Clin Biomech (Bristol, Avon), 21(8), 781-789. doi:10.1016/j.clinbiomech.2006.04.010

31. Moher, D., Liberati, A., Tetzlaff, J., Altman, D. G., \& The, P. G. (2009). Preferred reporting items for systematic reviews and meta-analyses: The PRISMA statement. PLOS Medicine, 6(7), e1000097. doi:10.1371/journal.pmed.1000097

32. Moseley, A. M., Herbert, R. D., Sherrington, C., \& Maher, C. G. (2002). Evidence for physiotherapy practice: A survey of the Physiotherapy Evidence Database (PEDro). Australian Journal of Physiotherapy, 48(1), 43-49. doi:10.1016/S0004-9514(14)60281-6

33. Mulroy, S. J., Hatchett, P., Eberly, V. J., Haubert, L. L., Conners, S., \& Requejo, P. S. (2015). Shoulder strength and physical activity predictors of shoulder pain in people with paraplegia from spinal injury: prospective cohort study. Phys Ther, 95(7), 1027-1038. doi:10.2522/ptj.20130606

34. Mulroy, S. J., Thompson, L., Kemp, B., Hatchett, P. P., Newsam, C. J., Lupold, D. G., . . . Gordon, J. (2011). Strengthening and optimal movements for painful shoulders (STOMPS) in chronic spinal cord injury: a randomized controlled trial. Phys Ther, 91(3), 305-324. doi:10.2522/ptj.20100182

35. Nash, M. S., van de Ven, I., van Elk, N., \& Johnson, B. M. (2007). Effects of circuit resistance training on fitness attributes and upper-extremity pain in middle-aged men with paraplegia. Arch Phys Med Rehabil, 88(1), 70-75. doi:10.1016/j.apmr.2006.10.003

36. Nawoczenski, D. A., Ritter-Soronen, J. M., Wilson, C. M., Howe, B. A., \& Ludewig, P. M. (2006). Clinical trial of exercise for shoulder pain in chronic spinal injury. Phys Ther, 86(12), 16041618. doi:10.2522/ptj.20060001

37. Neal, B. S., Lack, S. D., Lankhorst, N. E., Raye, A., Morrissey, D., \& van Middelkoop, M. (2019). Risk factors for patellofemoral pain: a systematic review and meta-analysis. British Journal of Sports Medicine, 53(5), 270-281. doi:10.1136/bjsports-2017-098890

38. Niederbracht, Y., Shim, A. L., Sloniger, M. A., Paternostro-Bayles, M., \& Short, T. H. (2008). Effects of a shoulder injury prevention strength training program on eccentric external rotator muscle 
strength and glenohumeral joint imbalance in female overhead activity athletes. J Strength Cond Res, 22(1), 140-145. doi:10.1519/JSC.0b013e31815f5634

39. Opar, D. A., Williams, M. D., \& Shield, A. J. (2012). Hamstring strain injuries: factors that lead to injury and re-injury. Sports Med, 42(3), 209-226. doi:10.2165/11594800-000000000-00000

40. Putzke, J. D., Richards, S. J., Hicken, B. L., \& DeVivo, M. J. (2002). Interference due to pain following spinal cord injury: important predictors and impact on quality of life. Pain, 100(3), 231-242. doi:10.1016/s0304-3959(02)00069-6

41. Rice, L. A., \& Rice, I. M. (2017). Evidenced based education interventions to preserve upper limb function among full time manual wheelchair users. Medical Research Archives, 5(3). doi:10.18103/mra.v5i3.1038

42. Serra-Añó, P., Pellicer-Chenoll, M., García-Massó, X., Morales, J., Giner-Pascual, M., \& González, L. M. (2012). Effects of resistance training on strength, pain and shoulder functionality in paraplegics. Spinal Cord, 50(11), 827-831. doi:10.1038/sc.2012.32

43. Steuri, R., Sattelmayer, M., Elsig, S., Kolly, C., Tal, A., Taeymans, J., \& Hilfiker, R. (2017). Effectiveness of conservative interventions including exercise, manual therapy and medical management in adults with shoulder impingement: a systematic review and meta-analysis of RCTs. $\mathrm{Br}$ J Sports Med, 51(18), 1340-1347. doi:10.1136/bjsports-2016-096515

44. Timmins, R. G., Bourne, M. N., Shield, A. J., Williams, M. D., Lorenzen, C., \& Opar, D. A. (2016). Short biceps femoris fascicles and eccentric knee flexor weakness increase the risk of hamstring injury in elite football (soccer): a prospective cohort study. Br J Sports Med, 50(24), 1524-1535. doi:10.1136/bjsports-2015-095362

45. Treiber, F. A., Lott, J., Duncan, J., Slavens, G., \& Davis, H. (1998). Effects of Theraband and lightweight dumbbell training on shoulder rotation torque and serve performance in college tennis players. Am J Sports Med, 26(4), 510-515. doi:10.1177/03635465980260040601

46. Ustunkaya, O., Edeer, A. O., Donat, H., \& Yozbatiran, N. (2007). Shoulder pain, functional capacity and quality of life in professional wheelchair basketball players and non-athlete wheelchair users. The Pain Clinic, 19(2), 71-76. doi:10.1179/016911107X268657

47. Van Cutsem, M., \& Duchateau, J. (2005). Preceding muscle activity influences motor unit discharge and rate of torque development during ballistic contractions in humans. The Journal of physiology, 562(Pt 2), 635-644. doi:10.1113/jphysiol.2004.074567

48. van Drongelen, S., de Groot, S., Veeger, H. E., Angenot, E. L., Dallmeijer, A. J., Post, M. W., \& van der Woude, L. H. (2006). Upper extremity musculoskeletal pain during and after rehabilitation in wheelchair-using persons with a spinal cord injury. Spinal Cord, 44(3), 152-159. doi:10.1038/sj.sc.3101826

49. Van Straaten, M. G., Cloud, B. A., Morrow, M. M., Ludewig, P. M., \& Zhao, K. D. (2014). Effectiveness of home exercise on pain, function, and strength of manual wheelchair users with spinal cord injury: a high-dose shoulder program with telerehabilitation. Arch Phys Med Rehabil, 95(10), 1810-1817.e1812. doi:10.1016/j.apmr.2014.05.004

50. Walford, S. L., Requejo, P. S., Mulroy, S. J., \& Neptune, R. R. (2019). Predictors of shoulder pain in manual wheelchair users. Clin Biomech (Bristol, Avon), 65, 1-12. doi:10.1016/j.clinbiomech.2019.03.003 
51. Waring, W. P., \& Maynard, F. M. (1991). Shoulder pain in acute traumatic quadriplegia. Paraplegia, 29(1), 37-42. doi:10.1038/sc.1991.5

52. Werkhausen, A., Albracht, K., Cronin, N. J., Paulsen, G., Bojsen-Møller, J., \& Seynnes, O. R. (2018). Effect of training-induced changes in achilles tendon stiffness on muscle-tendon behavior during landing. Front Physiol, 9, 794. doi:10.3389/fphys.2018.00794

53. Wilk, K. E., Obma, P., Simpson, C. D., Cain, E. L., Dugas, J. R., \& Andrews, J. R. (2009). Shoulder injuries in the overhead athlete. J Orthop Sports Phys Ther, 39(2), 38-54. doi:10.2519/jospt.2009.2929

54. World Health Organization. (2008). Guidelines on the Provision of Manual Wheelchairs in Less-Resourced Settings. Switzerland. 